\title{
ОБСЛЕДОВАНИЕ ОСНОВАНИЙ ГИДРОУЗЛА НА р. МАТТА МЕТОДОМ ЭЛЕКТРОТОМОГРАФИИ (Центральная ЯкУТИя)
}

\author{
Бажин К. И., Готовцев С. П., Сыромятников И. И. \\ ФГБУН Институт мерзлотоведения им. П. И. Мельникова СО РАН, г. Якутск \\ E-mail: kbazhin@gmail.com,gotovcev@mpi.ysn.ru,igor@mpi.ysn.ru
}

\begin{abstract}
Приведены результаты использования метода электротомографии для изучения состояния основания гидроузла на р. Матта в с. Бердигестях (Центральная Якутия). По геофизическим работам, проведенным в нижнем бьефе плотины, установлено, что талик под старым руслом реки распространяется на глубину более 14 м, а вдоль остальной части плотины талик приурочен к верхней части разреза и залегает в интервале глубин от 2.5 до 6.5 м. Проведенное бурение показало, что породы в талике водонасыщенные. Температурные замеры указывают на талое состояние основания плотины на глубину более 11 м. Удельное сопротивление талых пород изменяется от 20 до 70 Ом·м для суглинков, от 70 до 320 Ом·м для песков, а для мерзлых песчаников от 300 до 1200 Омм.
\end{abstract}

Ключевые слова: мерзлота, гидроузел, электротомография, плотина, талик, удельное электрическое сопротивление, бурение.

DOI: 10.34078/1814-0998-2020-4-55-61

\section{ВВЕДЕНИЕ}

Территория Центральной Якутии по природным условиям не обеспечена достаточным количеством воды. Поэтому, начиная с 60-х гг. прошлого века, проблема накопления воды рядом с населенными пунктами стала решаться путем строительства низконапорных земляных плотин на малых реках. Особенно много плотин строилось в Чурапчинском, Мегино-Кангаласском, Таттинском, Амгинском и Горном улусах. Если первые плотины строились хозспособом - стихийно, то начиная с 1980-х гг. такие стройки стали носить более систематичный характер.

По результатам исследований сотрудников Института мерзлотоведения установлено, что в Центральной Якутии за последние 40 лет температура воздуха повысилась более чем на $2.5^{\circ} \mathrm{C}$ (Балобаев и др., 2009; Кириллина, 2013). Потепление климата привело к снижению надежности и прочности гидротехнических сооружений. Наглядными примерами являются произошедшие аварии в 2014 и 2015 г. на плотинах водохранилищ «Сири-Холлогос» (Чурапчинский улус) и «Усун-Эбэ» (Таттинский). Для обеспечения безаварийной эксплуатации гидротехнических сооружений следует вести постоянные наблюдения 2020 за их состоянием. Наблюдения в скважинах предоставляют информацию лишь о состоянии сооружения в точке, тогда как с помощью геофизических методов можно получить информацию о состоянии всего сооружения. Ввиду того, что геофизические методы являются методами неразрушающего контроля, их безопасно применять в любой сезон года для выявления возникающих опасных процессов в теле, основании и примыканиях плотин гидроузлов, а также вести мониторинг (Великин, Шестернев, 2015).

В целях изучения криолитологического строения отложений, слагающих ложе плотины на p. Матта, а также для установления зон фильтрации воды из водохранилища колонковым способом были пробурены две скважины глубиной до 12 м. Исходя из поставленной цели, скважину необходимо было задать в пределах подруслового талика, считая его наиболее вероятным путем фильтрации воды из водохранилища. Для уточнения предположения о наличии фильтрации были проведены геофизические работы методом геоэлектрической томографии.

\section{ОБЪЕКТ ИССЛЕДОВАНИЯ}

Гидроузел «Матта» расположен на р. Матта, протекающей по территории с. Бердигестях Горного улуса Республики Саха (Якутия) - РС (Я) и предназначен для обеспечения водой населения этого села. Река Матта принадлежит к бассейну р. Лена, 
является водотоком II порядка длиной 195 км и площадью водосборного бассейна 4110 км². Среднегодовой расход воды в районе с. Бердигестях составляет 1.19 км$^{3}$. Тип питания смешанный: 60$70 \%$ составляют талые воды, $10-20 \%$ - дождевые, а остальная часть приходится на подземное или поверхностное питание (Биянов и др., 1989; Чжан и др., 2019).

Климат района характеризуется длительной холодной и снежной зимой, коротким, но сравнительно теплым летом. Средняя годовая температура воздуха в районе составляет $-11.1^{\circ} \mathrm{C}$. Средняя месячная температура января $-41.4^{\circ} \mathrm{C}$. Абсолютный минимум температуры воздуха в январе $-65.0^{\circ} \mathrm{C}$, абсолютный максимум равен $+37.0^{\circ} \mathrm{C}$ (июль). Годовое количество осадков 307 мм. Преобладают западные и северо-западные ветра. Испарение с водной поверхности составляет в среднем около 400 мм в год (Чжан и др., 2019).

Водохранилище было введено в строй в сентябре 1991 г. Эксплуатирующей организацией является Центральный филиал ГБУ «Упрмелиоводхоз МСХиПП РС (Я)». Полный объем водохранилища составляет $3470 \mathrm{~m}^{3}$. Длина водохра- нилища 4.8 км, ширина - от 300 до 700 м. Плотина гидроузла «Матта» талого типа отсыпана гравийно-галечным грунтом с супесчаным заполнителем, имеет длину 774 м, высоту 11 м (рис. 1) и напор 5 м.

Плотина снабжена трубчатым водосбросом из 16 металлических труб диаметром 1420 мм, предназначенным для отвода вод при наполнении водохранилища.

Для содержания плотины в мерзлом состоянии она была оборудована 18 жидкостнозамораживающими установками с шагом через 2 м. Глубина колонок до 14 м. В настоящее время они не работают.

Район водохранилища приурочен к зоне распространения многолетнемерзлых пород (ММП) мощностью до 500-600 м. Глубина сезонного протаивания составляет 2.0-2.5 м. Сильноминерализованные подмерзлотные воды вскрываются на глубине 500-600 м. В теплый период года в деятельном слое накапливаются надмерзлотные талые воды типа верховодки с незначительным дебитом. Температура на глубине годовых колебаний изменяется от -3 до $-5^{\circ} \mathrm{C}$.
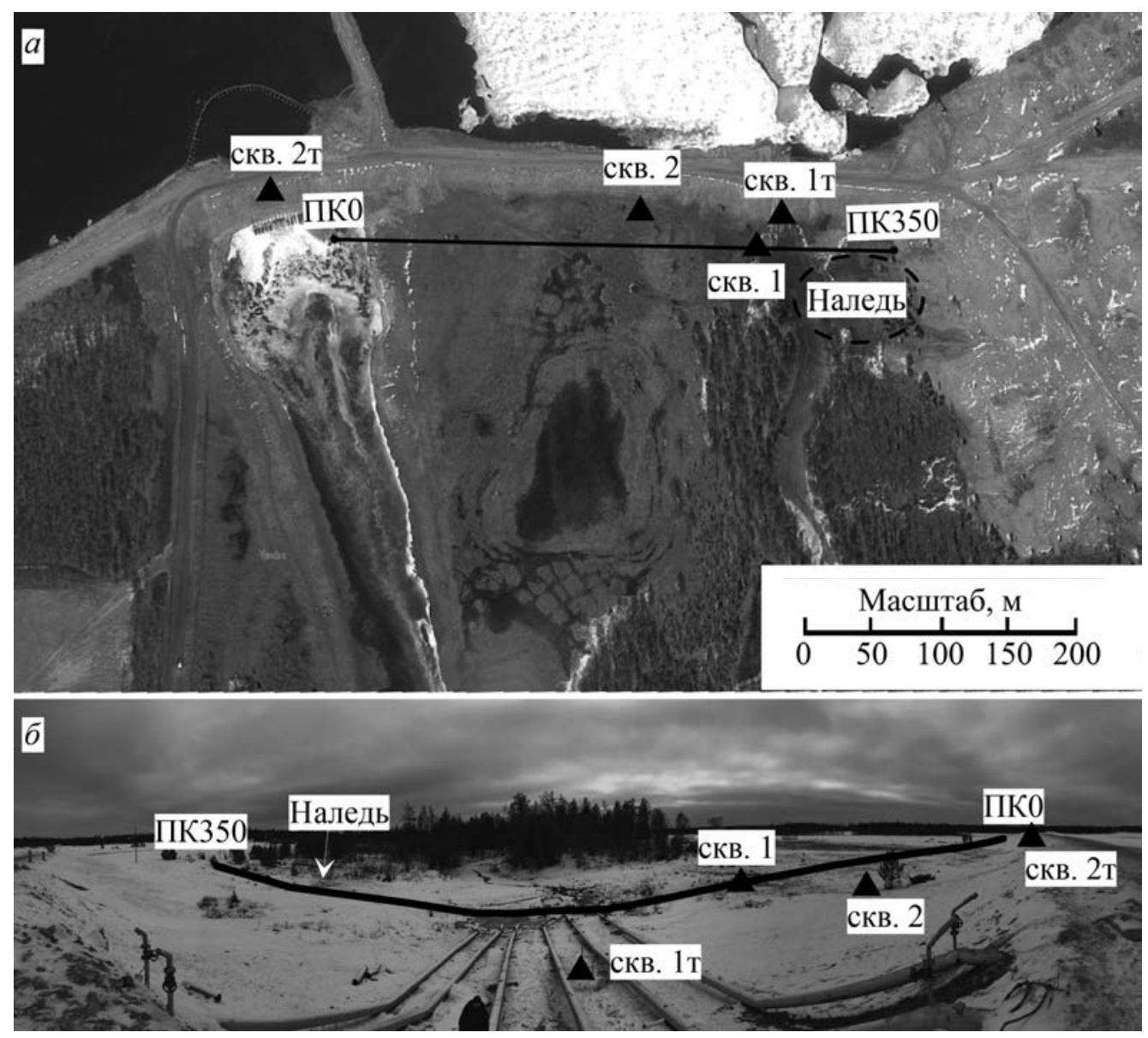

Puc. 1. Расположение профиля электротомографии и скважин на космоснимке (Yandex) (a) и вид на профиль с плотины (б)

Fig. 1. Location of the profile of electrical resistivity tomography and boreholes in a space photograph (Yandex) (a) and view of the profile from the dam $(\sigma)$ 
Основная часть створа плотины проходит по высокой пойме, представляющей древнее ложе руч. Матта.

\section{Буровые работы}

В октябре 2016 г. после проведения геофизических работ были пробурены 2 скважины. Скважина 1 глубиной 11 м пробурена на правом бере- ные наблюдения проведены в скважине около сифонного водосброса и в скважине, пробуренной в основании плотины над старым руслом p. Матта. Замеры, проведенные 20 октября 2016 г., показали, что грунты в скв. 1 талые на глубину более 11 м, а в скв. 2 только в интервале от 1.9 до 4.2 м (рис. 3).

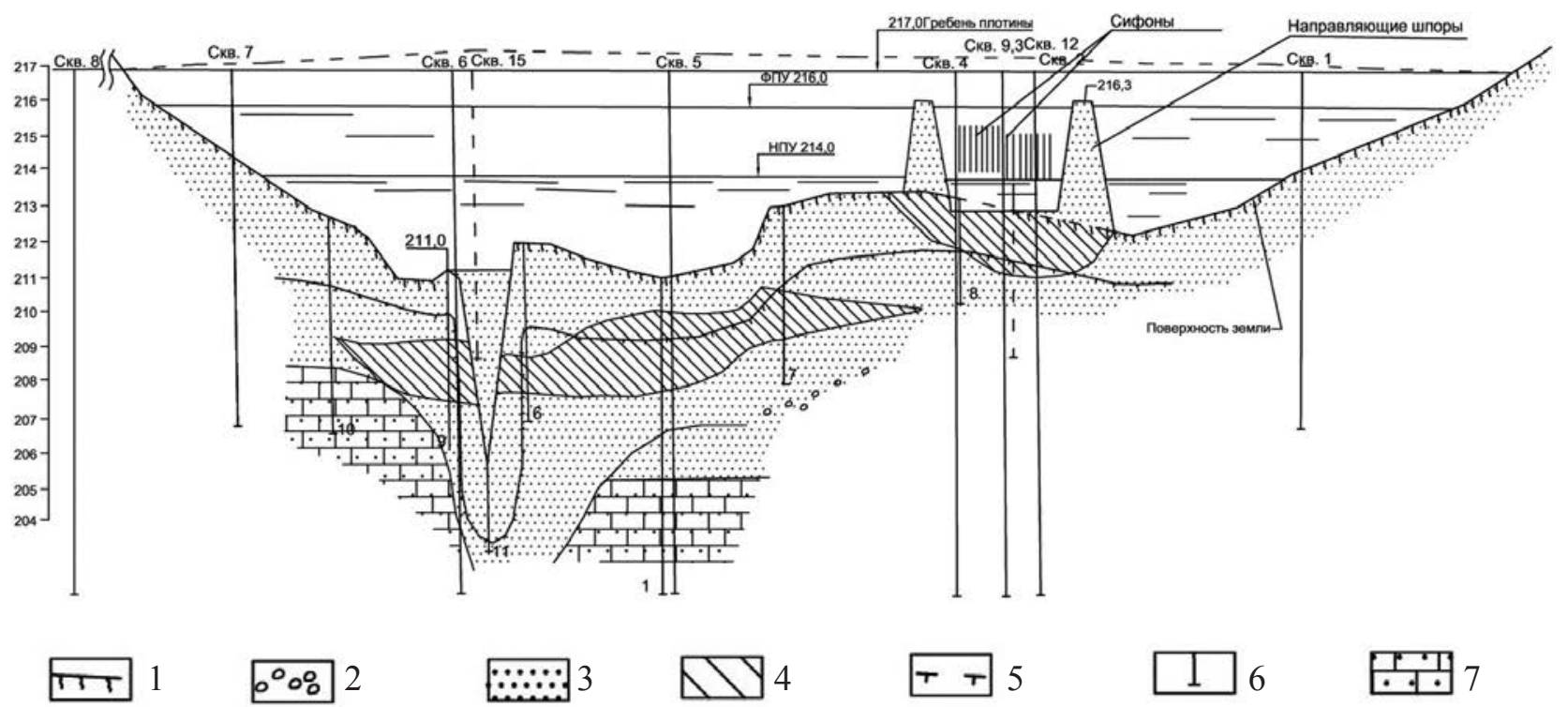

Pис. 2. Разрез основания плотины на р. Матта на момент строительства (Чжан и др., 2019): 1 - почвеннорастительный слой; 2 - галька; 3 - песок; 4 - суглинок; 5 - граница кровли ММП; 6 - буровая скважина; 7 - юрский песчаник

Fig. 2. Section of the dam base on the Matta River at the time of construction (Zhang et al., 2019): 1 - soil-vegetation layer; 2 - pebbles; 3 - sand; 4 - loam; 5 - permafrost table; 6 - borehole; 7 - Jurassic sandstone

гу старого русла р. Матта. Скважина 2 глубиной 12 м пройдена в основании плотины в 50 м западнее скв. 1.

Установлено, что породы нижнего бьефа плотины в местах бурения находятся в талом состоянии с дневной поверхности до забоя в скв. 1, а в скв. 2 до 9 м. При бурении происходил провал бурового снаряда. Выход керна на талых грунтах не превышал 15\%. Бурением в скв. 1 были вскрыты разнозернистые светло-серые пески, с 9.5 м супеси. Скважина 2 вскрыла супесь до глубины 3.5 м, песок разнозернистый до 9 м и с 9 м до забоя песок мерзлый (рис. 5). При строительстве гидроузла проведенные буровые работы показали, что основание сложено песками с линзами суглинков, залегающими на юрских песчаниках (Чжан и др., 2019) (рис. 2).

\section{Термометрические наблюдения}

Замеры температуры были проведены в двух скважинах, пробуренных при организации сети температурного мониторинга плотины. В настоящее время в рабочем состоянии осталось всего несколько скважин. Температур-

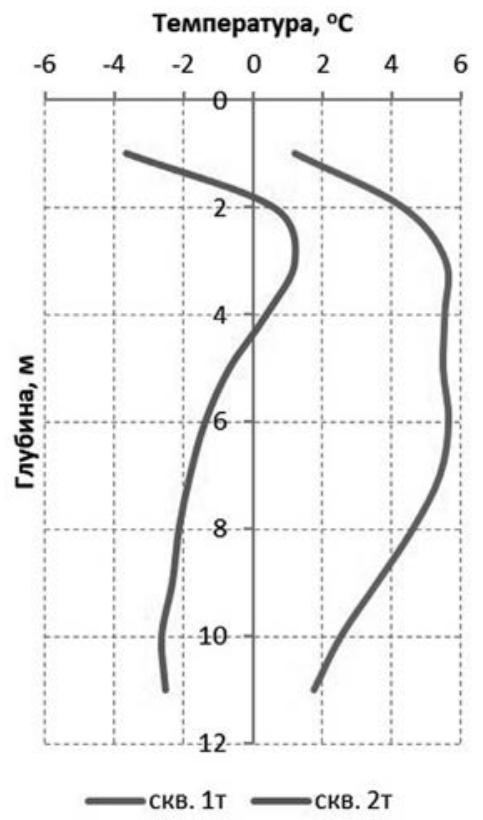

Puc. 3. Температура грунтов в скв. 1т и 2т (20.10.2016)

Fig. 3. Soil temperature in boreholes $1 \mathrm{t}$ and $2 \mathrm{t}$ $(20.10 .2016)$ 


\section{Геофизические исследования}

Метод геоэлектрической томографии - это комбинация вертикальных электрических зондирований и электропрофилирования для решения задач по изучению сред, значительно отличающихся от горизонтально слоистых (Бобачев и др., 2006). Примером таких сред может являться техногенно измененная геокриологическая среда вследствие возведения гидротехнического сооружения. Ранее сотрудниками Института мерзлотоведения метод электротомографии был успешно применен на ГТС Западной Якутии (Beликин, 2013; Бажин, 2016).

Работы по изучению состояния основания изученного гидроузла велись с использованием многоканальной многоэлектродной электроразведочной станции «СКАЛА-64» производства фирмы «КБ Электрометрия» (г. Новосибирск). В процессе работ использовались 4-электродная установка Шлюмберже и дипольно-осевая установка. Шаг между электродами изменялся от 2 м. Высотно-плановую привязку осуществляли

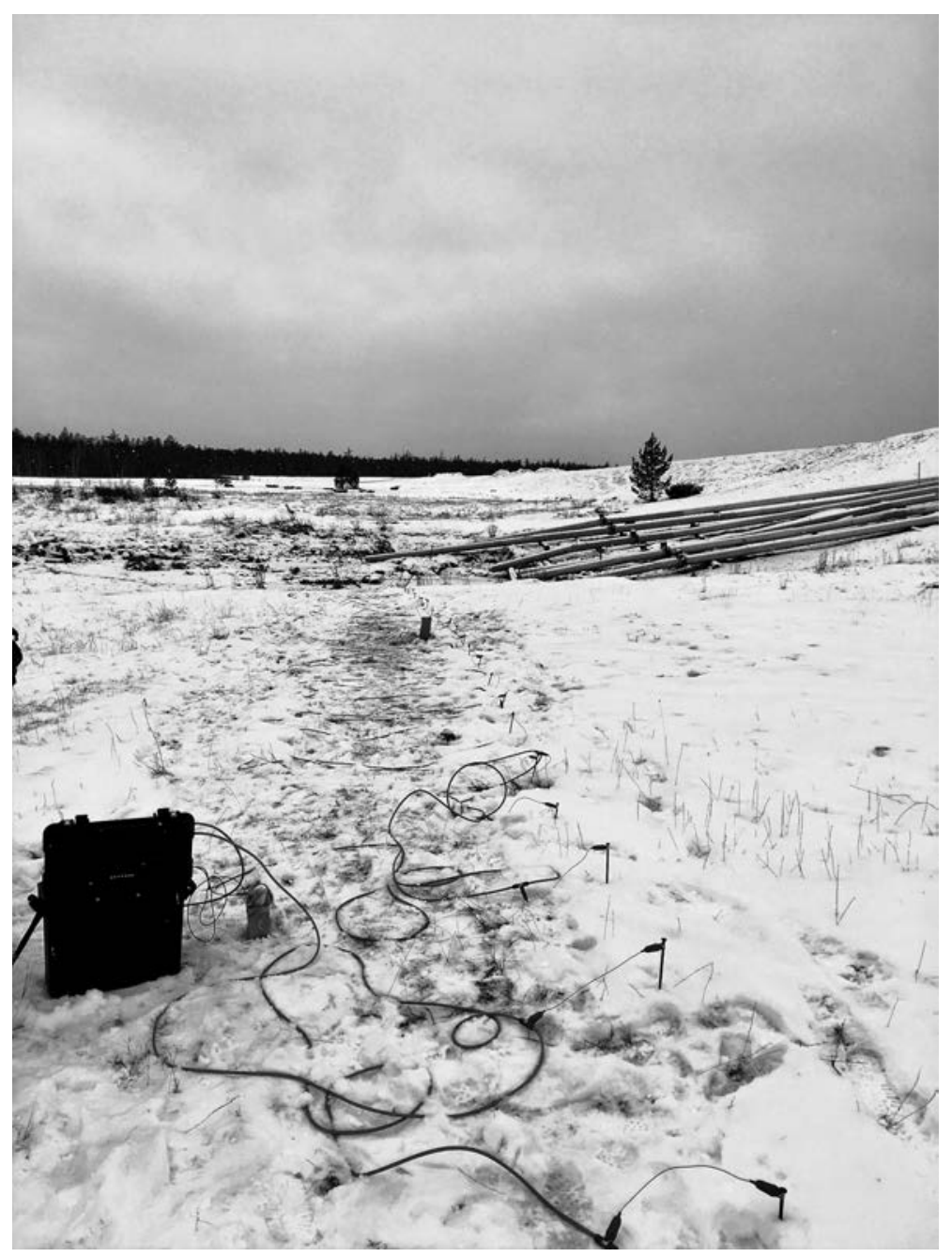

Pис. 4. Расположение станции «СКАЛА-64» и кос на профиле

Fig. 4. Location of the "SKALA-64" station and electrical cables on the profile с использованием GPS приемника Garmin 62s c точностью 3 м. Для работы применяли фирменные косы, имеющие 32 медные жилы диаметром 0.25 мм, к которым подключались по 32 электрода. Для заземления электродов использовали стальные нержавеющие стержни длиной $30 \mathrm{~cm}$. Электроды подключаются к косам по 32 шт. на каждой. Всего 2 косы по 160 м, поэтому за одну расстановку при шаге между электродами 2 м измеряли профиль длиной 126 м. В ходе полевых работ электроразведочные косы раскладывали на заранее намеченном профиле по прямой линии. Заземленные электроды подключали к косам, а косы - к станции, которая располагалась в центре профиля (рис. 4).

Переходное заземление изменялось от 0.5 до 10 кОм. Напряжение генератора устанавливали в пределах 200-400 В. Длительность импульса тока выбирали равной 80 мс. Значение тока в генераторной линии составляло от 3.5 до 890 мА.

Результаты измерений анализировали в программе RiPPP 1.31, а двумерная инверсия проводилась в программе ZondRes2D. В целях повышения качества геоэлектрического разреза для инверсии использовали сразу два набора данных с диполь-дипольной установки и установки Шлюмберже (Балков и др., 2012).

Профиль измерений располагали в нижнем бьефе плотины. Начало на западном конце плотины, конец в русле, образованном временными потоками воды через сифоны. Длина профиля $350 \mathrm{M}$.

Интерпретация геоэлектрических разрезов базировалась на априорной информации о мерзлотногеологическом строении участка, полученной при бурении скважин и результатах предшествовавших строительству результатов изысканий. На рис. 5 приведено сопоставление геоэлектрического разреза и результатов бурения. При сопоставлении результатов выявлено, что талые суглинистые отложения обладают значениями УЭС 30-60 Ом'м, талые пески 70-300 Ом·м, мерзлые пески - более 300 Ом'м. Полученные значения согласуются с приведенными данными в СП 11-105-97 (2004).

Установлено, что на профиле (рис. 6) в верхней части выделяется чередование талых сухих песков мощностью от 0.5 до 3.5 м и суглинков мощностью от 1.5 до 10 м. Ниже расположены водонасыщенные пес- 


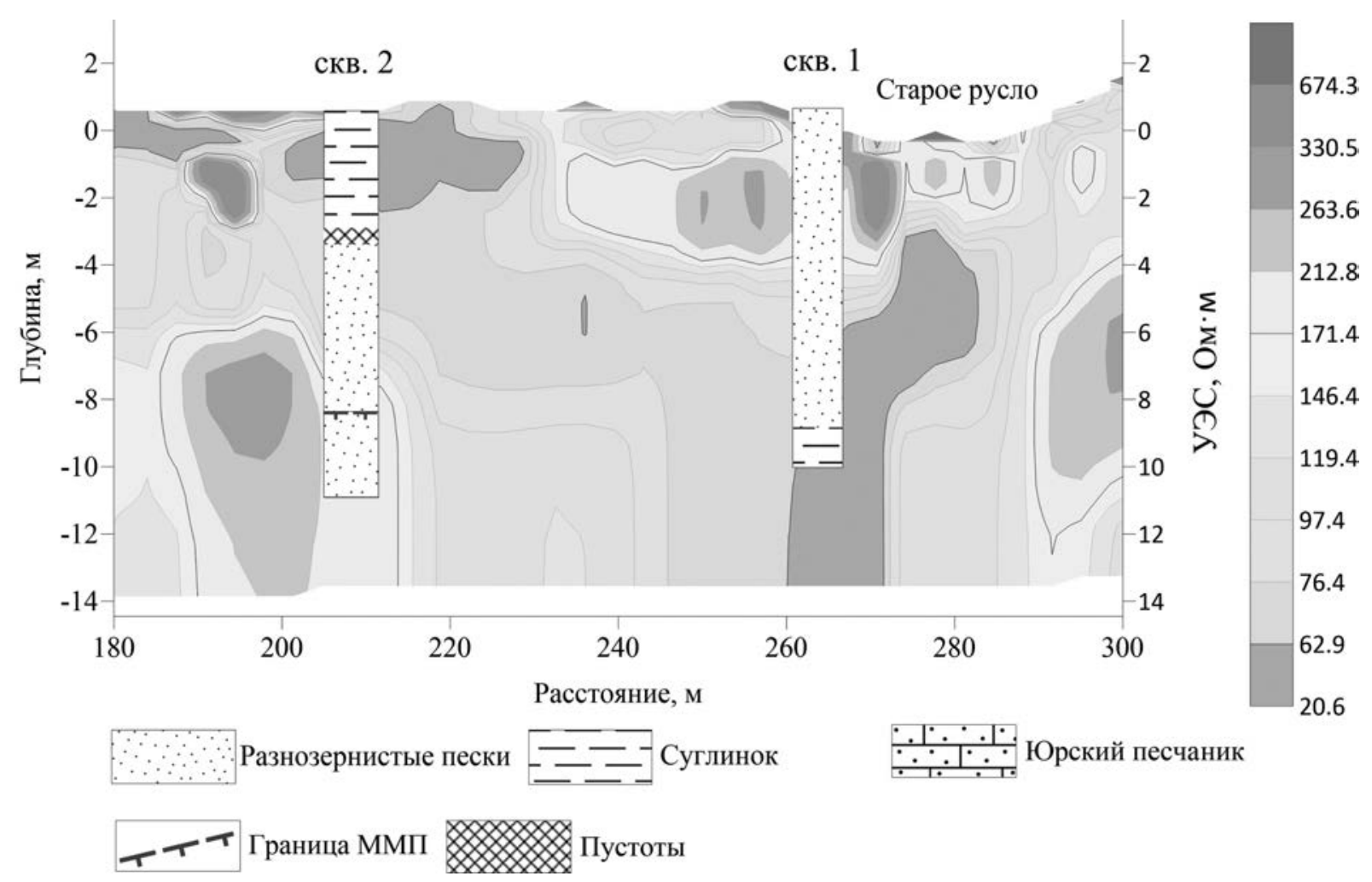

Puc. 5. Сопоставление геоэлектрического разреза и данных бурения

Fig. 5. Comparison of the geoelectric section and the drilling data

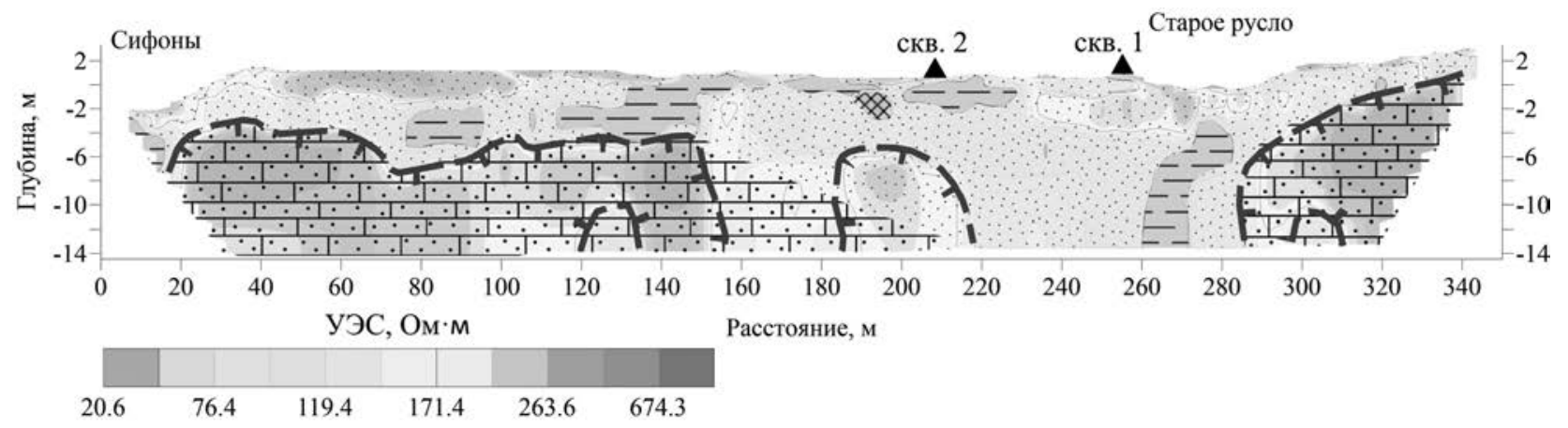

Puc. 6. Геоэлектрический разрез с интерпретацией по измеренному профилю. Условные обозначения см. на рис. 5

Fig. 6. Geoelectric section with the interpretation by the measured profile. For the Legend see Fig. 5

ки. Под ними залегают частично мерзлые юрские песчаники (УЭС 300-1200 Ом•м). Под старым руслом р. Матта выявлен водонасыщенный талик мощностью более 14 м и шириной 7080 м. Наличие талика подтверждается проведенными температурными измерениями в скв. 1т (см. рис. 3). Вероятно, по низким значениям УЭС (140-170 Ом·м) выделяется зона протаивания песчаников в интервале 150-180 м от начала профиля. В районе скв. 2 на глубине 1.3-3.3 м выделяется локальная зона повышенных УЭС (200450 Ом•м), вероятно, связанная с пустотами, так как в ней наблюдался провал бурового снаряда на интервале глубин 2.9-3.3 м. В нижнем горизонте юрских песчаников выделяются две зоны пониженных УЭС (70-100 Ом·м), интерпретируемые нами как талые.

\section{ВЫВОДЫ}

Проведенный нами комплекс работ позволил установить, что основание плотины находится в талом состоянии в промежутке между старым руслом и водопропускными сифонами. Наибольшая глубина талых пород (более 14 м) наблюдается под старым руслом р. Матта. В остальной части разреза мощность талых пород варьирует в интервале от 2.5 до 6 м. Опасение вызывает наличие областей низких УЭС на расстояниях 120130 и 300-310 м в песчаниках с глубины 10 м и 
область низких УЭС (40-170 Ом·м) на расстоянии 155-185 м от начала. Вероятно, в этих местах происходит оттаивание мерзлоты и в дальнейшем возможна фильтрация воды из водохранилища. Важным обстоятельством является то, что породы находятся в водонасыщенном состоянии. Наличие воды в талом горизонте указывает на то, что происходит фильтрация из водохранилища. Также фактором, указывающим на наличие фильтрации, является возникновение наледи, отмеченной нами в восточной части плотины. Талые водонасыщенные породы в совокупности с наличием пустот могут привести к разрушению плотины.

Проведенные расчеты (Тананаев, 2011) показывают, что при нарушении целостности плотины возможно подтопление сооружений пос. Бердигестях. Если учесть изменение среднегодовой температуры в пос. Бердигестях за последние 50 лет (Кириллина, 2013) более чем на $2^{\circ} \mathrm{C}$, отсутствие постоянного наблюдения за гидроузлом (Лоскин, Кныш, 2018) и текущее состояние основания плотины, то возникновение аварийной ситуации не кажется маловероятным.

В связи этим авторам так же, как и в статье (Лоскин, Кныш, 2018), хотелось бы отметить необходимость создания постоянной температурной мониторинговой сети, а также проведения регулярных геофизических исследований на всех гидроузлах Центральной Якутии. Это позволило бы избежать негативных последствий и вовремя принимать необходимые меры по устранению неисправностей в работе гидротехнического сооружения.

\section{ЛИТЕРАТУРА}

Бажин К. И. Возможности электротомографии для определения границ распространения талика в береговом примыкании плотины на р. Сытыкан : сб. науч. тр. (по материалам IX Междунар. науч.-практ. конф. студентов, аспирантов и молодых ученых). Пермь : ПГНИУ, 2016. Т. 1. С. 260-265.

Балков Е. В., Панин Г. Л., Манштейн Ю. А., Манштейн A. К., Белобородов В. А. Электротомография: аппаратура, методика и опыт применения // Геофизика. 2012. № 6. С. 54-63.

Балобаев В. Т., Скачков Ю. Б., Шендер Н. И. Прогноз изменения климата и мощности мерзлых пород Центральной Якутии до 2200 года // География и природные ресурсы. 2009. № 2. С. 50-56.

Биянов Г. Ф., Когодовский О. А., Макаров В. И. Грунтовые плотины на вечной мерзлоте. Якутск : Ин-т мерзлотоведения СО АН СССР, 1989. 152 с.

Бобачев А. А., Горбунов А. А., Модин И. Н., Шев$н и н$ B. A. Электротомография методом сопротивлений и вызванной поляризации // Приборы и системы разведочной геофизики. 2006. № 2. С. 14-17.

Великин С. А. Возможности использования геофизических методов при изучении состояния гидротехнического сооружения в криолитозоне на примере накопителя минерализованных вод Тымтайдаах // Инженерные изыскания. 2013. № 9. С. 52-59.

Великин С. А., Шестернев Д. М. Научнометодические основы геофизического мониторинга гидро- и горнотехнических сооружений в криолитозоне Якутской алмазоносной провинции : Материалы конференции «Инженерная, угольная и рудная геофизика-2015. Современное состояние и перспективы развития». Москва, 2015. С. 184-189.

Кириллина К. С. Современные тенденции изменения климата Республики Саха (Якутия) // Ученые записки Рос. гос. гидрометеоролог. ун-та. 2013. № 30. С. 69-77.

Лоскин М. И., Кныли А. И. Современное состояние гидротехнических сооружений объектов сельскохозяйственного водоснабжения центральной зоны Якутии (на примере гидротехнических сооружений объектов сельскохозяйственного водоснабжения ГБУ «Упрмелиоводхоз» МСХиПП РС (Я)) //Аграрный вестник Урала. 2018. № 4 (171). С. 49-54.

СП 11-105-97. Инженерно-геологические изыскания для строительства. Ч. VI. Правила производства геофизических исследований / Госстрой России. Москва : ПНИИИС Госстроя России, 2004. 49 с.

Тананаев Н. И. Гидротехнические мероприятия на реках Якутии: обоснованность и эффективность // Наука и техника в Якутии. 2011. № 2 (21). С. 24-28.

Чжан Р. В., Великин С. А., Кузнеиов Г. И., Крук Н. В. Грунтовые плотины в криолитозоне России. Новосибирск : Гео, 2019. 427 с.

Якупов В. С. Геофизика криолитозоны. Якутск : Изд-во ЯГУ, 2008. 342 с.

Поступила в редакциюю 20.04.2017 2.

Поступила после доработки 18.11.2019 2. 


\title{
SURVEY OF THE DAM BASE ON THE MATTA RIVER (Central Yakutia) BY ELECTRICAL RESISTIVITY TOMOGRAPHY
}

\author{
K. I. Bazhin, S. P. Gotovtsev, I. I. Syromyatnikov \\ Melnikov Permafrost Institute SB RAS, Yakutsk
}

\begin{abstract}
The paper presents the results of using the method of electrotomography to study the state of the base of the waterworks on the Matta River in the village of Berdigestyakh (Central Yakutia). According to geophysical work carried out in the dam downstream, it was found that the talik under the old river bed extends to the depth of more than $14 \mathrm{~m}$, and along the rest of the dam, the talik is confined to the upper part of the section lying in the depth interval from 2.5 to $6.5 \mathrm{~m}$. Drilling showed that the rocks in the talik are water-saturated. Temperature measurements indicate the thawed state of the dam base to the depth of more than $11 \mathrm{~m}$. The specific resistance of thawed rocks varies from 20 to $70 \mathrm{Ohm} \cdot \mathrm{m}$ for loams, from 70 to $320 \mathrm{Ohm} \cdot \mathrm{m}$ for sand, and 300 to $1200 \mathrm{Ohm} \cdot \mathrm{m}$ for frozen sandstones.
\end{abstract}

Keywords: permafrost, waterworks, electrotomography, dam, talik, electrical resistivity, drilling.

\section{REFERENCES}

Balkov, E. V., Panin, G. L., Manstein, Yu. A., Manstein, A. K., Beloborodov, V. A., 2012. Electrotomography: Equipment, Methods and Application Experience, Russian Geophysics. 6, 54-63 [In Russian].

Balobaev, V. T., Skachkov, Yu. B., Shender, N. I., 2009. Forecast of Climate Change and Thickness of Frozen Rocks in Central Yakutia Before 2200, Geography and Natural Resources. 2, 50-56 [In Russian].

Bazhin, K. I., 2016. Possibilities of Electrotomography for Determining the Talik Distribution Boundaries in the Coastal Abutment of the Dam on the River Sytykan. Collection of Scientific Papers, by the Materials of the IX International Scientific and Practical Conference of Students, Graduate Students and Young Scientists. Perm, PSU. 260-265 [In Russian].

Biyanov, G. F., Kogodovsky, O. A., Makarov, V. I., 1989. Ground Dams on Permafrost. Yakutsk, Institute of Permafrost SB RAS [In Russian].

Bobachev, A. A., Gorbunov, A. A., Modin, I. N., Shevnin, V. A., 2006. Electrotomography by the Method of Resistance and Induced Polarization, Devices and Systems of Exploration Geophysics. 2, 14-17 [In Russian].

Kirillina, K. S., 2013. Current Trends in Climate Change in the Republic of Sakha (Yakutia), Proceedings of the Russian State Hydrometeorological University. 30, 69-77 [In Russian].

Loskin, M. I., Knysh, A. I., 2018. The Current State of Hydraulic Structures of Agricultural Water Supply Facilities in the Central Zone of Yakutia (Examplified by of Hy- draulic Structures of Agricultural Water Supply Facilities of the Uprmeliovodkhoz State Public Institution, MSHipp RS Ya), Agrarian Bulletin of the Urals. 4 (171), 49-54 [In Russian].

SP 11-105-97, 2004. Engineering and Geological Surveys for Construction. Part VI. Rules for Performing Geophysical Surveys, Gosstroy of Russia. Moscow, PNIIIS Gosstroy of Russia [In Russian].

Tananaev, N. I., 2011. Hydrotechnical Measures on the Rivers of Yakutia: Feasibility and Effectiveness, Nauka i Tekhnika in Yakutii. 2 (21), 24-28.

Velikin, S. A., 2013. Possibilities of Using Geophysical Methods in Studying the State of a Hydraulic Structure in the Permafrost Zone Using the Example of the Tymtaydaakh Mineralized Water Reservoir, Engineering Surveys. 9, 52-59 [In Russian].

Velikin, S. A., Shesternev, D. M., 2015. Scientific and Methodological Foundations of Geophysical Monitoring of Hydraulic and Mining Structures in the Permafrost Zone of the Yakut Diamondiferous Province, Materials of the Conference "Engineering, Coal and Ore Geophysics2015. Current State and Development Prospects». Moscow, 184-189 [In Russian].

Yakupov, V. S., 2008. Geophysics of the Cryolithozone. Yakutsk, Yakutsk State University [In Russian].

Zhang, R. V., Velikin, S. A., Kuznetsov, G. I., Kruk, N. V., 2019. Soil Dams in the Permafrost Zone of Russia. Novosibirsk, Geo [In Russian]. 